\title{
Analysis of Profitability and Risk in New Agriculture Using Dynamic Non-Linear Programming Model
}

\author{
Rakesh Kumar Sharma (Corresponding author) \\ Department of Economics, Government College for Girls (RKMV) \\ Shimla 171001, Himachal Pradesh, India \\ Tel: 91-941-809-5808Ｅ-mail: rakeshinshimla@yahoo.co.in \\ Prem Lall Sankhayan \\ Department of Ecology and Natural Resource Management (INA) \\ Norwegian University of Life Sciences (UMB), Box 5003, NO-1432 Aas, Norway \\ Ranveer Singh \\ Agro Economic Research Centre, Himachal Pradesh University \\ Summerhill, Shimla, Himachal Pradesh, India
}

\begin{abstract}
Cropping pattern in the Himalayan region of India has undergone a significant change in the recent past. Introduction of horticultural crops such as vegetables, fruits and flowers has led to more intensive agriculture. Such a change, resulting in higher incomes and improvements of the overall living conditions has, however, been accompanied with increased income risk. This emphasizes the need for proper analysis of the cropping pattern, at an appropriate scale, such as a micro watershed. This was achieved by constructing a dynamic non-linear programming model incorporating appropriate objective function, constraints and crop and livestock activity budgets along with risk component present in the gross returns. The model was then solved under alternate policy scenarios by using General Algebraic Modeling Systems (GAMS) for the next 20 years. The optimum cropping plans were then compared with each other and with the existing plan. Tomato and carnation are the preferred crops, if the sole objective is profit maximization. Optimum plan with risk consideration was also assessed by fixing the variance in gross returns at the current level. It reduced the area under tomato in rainy season by growing capsicum and beans. Similarly, peas replaced tomato in winter season and chrysanthemum replaced carnation. By comparing it with the existing plan, it can be inferred that the people are more concerned to risk than the profits. The profits and risks from floriculture are relatively very high as compared to other crops. By removing constraints in credit availability, irrigation facilities, transportation and market yards, large scale production of vegetables and flowers can help in raising the income level.
\end{abstract}

Keywords: Cropping pattern, Gross margins, Himachal Pradesh, Covariance

\section{Introduction}

Himalayan agricultural system is characterized by small landholdings and mixed crop-livestock farming practices (Tulachan \& Neupane, 1999). Rain-fed terraced fields, often with high slope, result in low productivity of crops. Increasing human population is putting more pressure on arable land in the rural areas (Gohp, 2002). This calls for urgent attention on the part of planners and policy makers for devising strategy to raise income levels and to improve the human environment (Pokhriyal \& Bist, 1998). Experience has shown that the state of substantial gains in crop and livestock production can be achieved through intensive farming, crop genetic improvement and better land management practices that help in the improvement of soil conservation and crop yields (Powell et al., 2004). Though the mountain areas find it difficult to increase resource use efficiency due to fragility and relative isolation, the subsidies and support system has helped in sustenance and development options in Himachal Pradesh (Jodha, 2005). In the past one decade or so, the response of cultivators in the region has been through the inclusion of vegetable and flower crops and improved 
breeds of cattle in the agricultural system. This has led to substantial increase in their incomes and living conditions, accompanied with changed levels of risk.

The effect of such a change in the agriculture over the last few years, therefore, needs to be closely monitored with respect to its profitability and risk. Because of the numerous complexities and the constraints involved in this phenomenon, the real world conditions can best be approximated through economic or bio-economic modeling approach. This requires systems approach to analyze the problem in totality rather than analyzing it in parts. Studies at micro watershed level are more effective for policy formulation and can be linked to greater issues at regional/national/international levels (Sankhayan et al., 2003). This study, therefore, represent one such effort where dynamic non-linear programming model is used for analyzing the profitability and risk in the newly emerged horticultural crops under alternate policy regimes at a micro watershed level in the state of Himachal Pradesh. It also aims at making some policy recommendations for eliminating certain constraints in horticultural development.

\section{Methods}

\subsection{The study area}

Himachal Pradesh has been divided into four agro-climatic zones on the basis of altitude, temperature, topography, rainfall and humidity (Chand, 1997). These are: (i) subtropical, sub montane and low hills (ii) sub temperate, sub humid mid hills (iii) wet temperate high hills (iv) dry temperate high hills and cold desert. The watershed under study i.e., Chabri, is situated in the third zone. It is located in the Shimla hills of western Himalayas in Solan district of Himachal Pradesh (Fig. 1). It measures $8.96 \mathrm{~km}^{2}$ and is catchments of Chabri rivulet that drains into Ashwani River. Located between $77^{\circ} 10^{\prime}$ and $77^{\circ} 12^{\prime}$ in the East and $30^{\circ} 57^{\prime}$ and $30^{\circ} 58^{\prime}$ in the North, the micro watershed is a small mountainous oval shaped valley with steep slopes, typical of the landscape pattern in the mid hill zone of the state of Himachal Pradesh.

Altitudes range from $1650 \mathrm{~m}$ to $1950 \mathrm{~m}$ above mean sea level. Average annual rainfall during the period 1993-2003 was $596 \mathrm{~mm}$ and snowfall was $65 \mathrm{~cm}$ (Gohp, 2005). Average daily temperatures vary from $-4^{\circ} \mathrm{C}$ to $28^{\circ} \mathrm{C}$ during the year. The micro watershed is bounded by Ashwani River to the north-west and south-west, by the boundary of Solan and Shimla districts to the north and by Giri River to the south-east. It has nine villages and 102 households having a human population of 703 people. The population density is rather low, i.e. 78 persons per $\mathrm{km}^{2}$.

Out of the total watershed land area, about 68.1 ha are under crop cultivation. According to the official records, about $58 \%$ of the watershed area is under forest owned by the state. The mixed farming system with crop cultivation, livestock rearing and forest product extraction is similar to other regions of the Himachal Pradesh (Sharma et al., 2008).

Out of 102 households, about $46 \%$ of the farmers own less than one ha land. Average family size in the watershed is 6.9 with an operational landholding of about 0.73 ha. Literacy rate is about $85.5 \%$, comparatively better among males. About $68 \%$ of the total population is active work force. Some of the workforce is also engaged in non-farm activities and supplementing the farm income of households. There are a very few people who are earning through wage labor. The major dependence for the livelihood of most households in the watershed is on mixed farming system.

\subsection{Data sources}

All the nine villages in the selected watershed were surveyed for the study. A list of all households in the villages was prepared and all the 102 households were interviewed for the required information. The household data on demographic profile, land holding, cropping pattern and input-output of crops and livestock was collected through a household survey. Information so obtained, pertains to the agricultural year 2005-06. For better assessment of the watershed utility, only the paid out costs have been included in the budgets.

Time series data on land use and cropping pattern as available for each village with the local revenue official was also taken into account while gathering first hand information. Data on price and yield of crops for the last five years were obtained from the Directorate of Land Records, Directorate of Agriculture, and the related study conducted in Agro-Economic Research Center, Shimla (Singh et al., 2006). Some data gaps were bridged through cooperative marketing societies, discussions with the farmers, extension workers, government officials, NGOs and local leaders in the study area.

\subsection{The model}

The dynamic mathematical programming bio-economic model developed by Sankhayan and Hofstad (Sankhayan \& Hofstad, 2001) at village level and later modified and used at watershed level in Nepal (Sankhayan et al., 2003) has been suitably modified to account for the conditions characteristic of the selected watershed in Himachal Pradesh. It is solved with the general algebraic modeling system (GAMS)/MINOS (Brooke et al., 1998). The model is solved for income optimization from crop and livestock activities and with due considerations to the risk in gross returns from crop activities over a time period of 20 years. Results for the existing scenario were then compared with the optimum plans with and without risk component and with the alternate model scenarios. 
The following sections discuss in more details the dynamic programming model in respect of its various components, such as the objective function, inputs and outputs, and constraints.

\subsubsection{Maximizing the net cash income from crops and animal activities}

The model considers a watershed aggregate utility maximization objective function that is realized by maximizing the net cash income from crop and animal activities under several constraints. This function can be expressed as follows:

$$
\text { Maximize } \sum_{t=1}^{T} 1 /(1+\partial)^{t} U_{t}
$$

where, $U_{t}$ is the total discounted gross margins from crop and animal activities in the $t^{\text {th }}$ year for the entire model horizon and the same is defined as:

$$
U_{t}=p_{t}^{c} x_{t}^{c}+p_{t}^{l} x_{t}^{l}
$$

where, $x_{t}^{c}$ and $x_{t}^{l}$ are the column vector representing units of crop and livestock units for each time period. Whereas

the land units are in hectare, the animals are taken as such. $p_{t}^{c}$ and $p_{t}^{l}$ are row vectors of annual gross margins per unit of crop and livestock in rupees. $\partial$ is the annual percent discount rate, taken as $5 \%$ per annum in this study, to convert the stream of gross margins over the model horizon into present value equivalent. $t$ is the time period measured in years over model horizon; $\mathrm{t}=1,2, \ldots, \mathrm{T}$, where $\mathrm{T}=20$.

The variations in yields and prices of crops over the last five years have been incorporated in the model with variance-covariance matrix as done by the Hazel (1971). This makes the risk equation quadratic and the dynamic model non-linear. The variance has also been discounted in the model so as to account for the level of risk over the years. Whereas discounting of income helps in analyzing the present value of the future income, the discounted variance in income over time (VIT) brings us closer to reality by ensuring that the risks in gross returns become less important with more distant future. The objective function for maximizing income is subjected to the following set of activities and constraints in the model:

\subsubsection{Activities used in the model}

Only crops and livestock product activities have been included in this model. Crops that are grown on at least half ha are included in the model. Budgets of these crops were prepared by incorporating gross margins. Similarly, the gross margins from livestock were also included. Income from off-farm activities, mainly the earnings from salaried jobs outside watershed and the forest activities, were not included in the model due to higher expenditure levels in urban centers and banned commercial activity in forest. The model provides for labor hiring for all activities. Though this is provided for each of the 12 months, the hiring is expected to take place only during the peak months. The growth rate of population was treated exogenous to the model and the same is given by the following equation:

$$
P_{t}=P_{0}(1+\rho)^{t}
$$

where, $\rho=$ average annual percent growth rate.

Like the human population, the livestock population in the watershed is assumed to grow at a constant rate over the model time period. Growth rate for each livestock unit was estimated from the figures obtained from livestock census conducted in the past. Given the ratio of workers to total population (RWP) and average working days per month (WDM), both as exogenous variables, labor availability during $\mathrm{m}^{\text {th }}$ month in the $\mathrm{t}^{\text {th }}$ year can be found out as follows:

$$
L A B O R_{m t}=R W P W D M_{m} \cdot P_{t}
$$

\subsubsection{Constraints in the model}

Households are assumed to make decisions under a number of constraints. Constraints for land were incorporated according to crop growing seasons, i.e., rainy (kharif) and winter (rabi) by different land use types, such as irrigated and unirrigated land. Because of incorporation of crop activities by annual crop seasons in the model, only annual land availability constraints were used within relatively homogenous land units. Labor availability constraints (man equivalent days) are considered according to months. The labor availability increases with growth of population over the run of the model. This can be supplemented through labor hiring. Only $15 \%$ of the annual gross margins have been 
kept available for working capital. This has been done with due considerations to high initial investment requirements for cash crops like flowers, their associated costs, and consumption requirements. This constraint has also been used for sensitivity in the model scenario.

\subsubsection{Model scenarios and calibrations}

In addition to the base scenario, which represents business as usual, four other scenarios have been introduced to analyze the dynamics of cropping patterns in the study watershed. A brief explanation of these scenarios is presented in Table 1. To represent the ground reality, model was calibrated for the base year in respect of cropping pattern as obtained from the survey data. The model was then run under different scenarios over a period of 20 years, i.e., from 2007 to 2026.

\section{Results and discussion}

\subsection{Existing cropping pattern in the watershed}

The cultivated land area in the watershed is mainly rain fed with two distinct cropping seasons in a year, namely, kharif (rains) and rabi (winters). Out of the total cultivable land area of 68.14 ha, only 31.44 ha of the land has year-round irrigation facilities, whereas, the 36.70 ha of the land is rain fed (Table 2).

The most widely cultivated crops during the kharif season are maize, tomato and capsicum, whereas wheat and barley are the dominant crops during the rabi season. Cash crops such as beans, potato, ginger and cabbage are also grown on some area. Farmers grow many other crops for self consumption, but due to the very small proportion of the land area, it is difficult to estimate it at household level, though the total area under such crops may be quite significant for the whole watershed. However, vegetable crops on unirrigated land are grown in kharif season only but on irrigated land it is grown in both seasons.

Over the last few years, the area under less remunerative crops has been rapidly declining, whereas, the area under horticultural crops (vegetables and flowers) has increased by 35\% over the period from 1990-91 to 2004-05 in this watershed area (Sharma et al., 2007). It also matches with the overall trends in Himachal Pradesh (Bhatti et al., 2002; Singh et al., 2006).

In the rabi season, due to the less availability of water and maintenance of soil fertility level for cash crops, a major part of the cultivable land is held as fallow. Crops such as maize, wheat and barley are still grown despite their low gross margins (Chand, 1997). Several factors like risk minimization, self sufficiency, and less labor and capital requirements are sustaining this practice.

Closer integration of farmers in the market economy is the driving force behind the shift in the cropping area from food grain crops to production of cash crops (Sharma, 2005; Sharma et al., 2007). Vegetables grown in this region are off-seasonal in nature and therefore, it fetches good prices in the market, whereas, the food grains are mainly grown for self consumption, but in case of vegetables, more than $90 \%$ of total produce goes to market as marketed-surplus (Singh et al., 2000).

The agricultural operations in the flower cultivation extend throughout the year in kharif and rabi seasons. Not only this activity is more profitable, but it also provides better utilization of household labor as the operations are spread more evenly over the year. Flower crops such as carnation, gladiolus, chrysanthemum and lily occupy about 8.19 ha of land. While carnation, lily and chrysanthemum require controlled conditions of poly house, the gladiolus is grown in the open fields. Gladiolus is grown mainly in those areas where the construction of poly houses is not feasible. Although the chrysanthemum can also be grown in open field, the farmers in this watershed prefer to cultivate it within uncovered structure of poly house, required for black out conditions in the later stages for speedier growth of flower to reap the better prices in market. Though per hectare profitability of gladiolus is very low in comparison to other flower crops, they are still grown at equal importance due to low investment and labor requirements. Lily is a newly introduced flower and occupies very little area in the watershed.

Flower cultivation which started in the mid nineties has become very popular now in this watershed, mainly due to favorable agro-climatic conditions, technical know-how and easy access to the markets. Availability of sufficient sunshine and mild weather even during the winter months, enable growers to produce cut flowers under relatively simple protected structures (Mysore \& Uva, 2000).

\subsection{Data inputs to the model}

\subsubsection{Crop and livestock budgets}

Traditional crops and cash crops are simultaneously grown in the watershed. Though the gross margins from flowers cultivation are very high in comparison to other crops (Table 3), but due to the constraints such as irrigation, leveled land, and high capital and labor requirements, it is produced only on about $12 \%$ of the cultivated land. Those who are not able to cultivate flowers due to these constraints, grow vegetable crops like capsicum, tomato, potato, beans, peas 
etc. In the watershed, only flower cultivation requires market borrowings, whereas, the cultivation of other crops is financed from past savings. Due to initial heavy investment requirements for poly house structures, per hectare cost of borrowings is very high for all flower crops except gladiolus, which is grown in open fields. By taking into account the durability of capital goods, the cost is split on yearly basis and interest payments are made at current rate of $12.5 \%$.

Traditional crops such as maize, wheat, barley and pulses are still grown on significant area, despite low gross margins. Among vegetables, capsicum requires more variable cost than others, whereas, the tomato is the crop with highest gross margins. But capsicum commands equal importance mainly due to less risk in price variation. Except the crops of flowers, cost of production of all crops is meted out from the past savings of the households.

Livestock rearing is also an important component of farming system in the watershed. Among all livestock heads, cross-bred cow realize highest gross margins to people followed by buffalo and local cows (Table 4). Though the rearing of other classes of livestock cannot be seen in isolation to the milk producing animal, their role in providing dung for farm-yard manure has a special significance in the context of cash crops' cultivation. Due to the insignificant contribution of this activity to gross income, and low variation in yield and output price, the risk from this activity is not considered in the model.

\subsubsection{Variations in gross returns over last five years}

Variations in the gross returns over the last five years have been included in the model (Table 5). A complete set of variance-covariance matrix was constructed with the last five year data of yield and output price. As the diagonal elements represent the variance, other elements denote the covariance among the crops. It has helped in introducing the risk element in economic model and finding the optimum cropping pattern. Among vegetables, the variance in gross returns during the last five years is highest in case of tomato followed by garlic and peas. Traditional crops like maize, wheat and barley have the lowest variance level. In floriculture, all the flowers have a high variance level but the carnation tops in the list followed by lily and gladiolus.

\subsection{Economic model and the dynamics of cropping pattern}

In the scenario 1, total discounted gross margins (TDGM) are calculated by fixing activities at present level over the entire model horizon. TDGM, which is the present value of income from crop and livestock activities over the model horizon, turns out 321,278 thousand rupees. In this business as usual scenario, the variance in gross returns (VIT) is estimated at 3,327,000 thousand rupees. This variance level, which emerges from the existing cropping pattern, represents the actual risk level taken by the people of this watershed. Preference for crop diversification over optimum plans is due to various reasons, such as risk aversion, bottleneck in capital, labor and irrigation, small land holdings, preferences for leisure, and less enterprise. Annual capital requirements for crop and livestock activities in the watershed are presently about 3,892 thousand rupees.

Scenario 2 is a true optimum plan with no considerations of risk. TDGM is maximized at a level of 785837 thousand rupees which is more than double the TDGM of base. Though true optimization plans can lead to the highest increase in income but such plans are risk inefficient (Olarinde et al., 2008). Only tomato is grown in both the seasons, in addition to the carnation flower (Fig. 2). Tomato is grown on significant land area in the existing plan, as it is a widely cultivated crop in the whole district due to favorable agro-climatic conditions, high productivity, and good quality of produce. The area under this crop, however, diminishes marginally over time horizon as a result of increase in land area under carnation.

Carnation is being cultivated in various suitable regions of the state due to better returns. In the rabi season, wheat is grown on un-irrigated land only after the middle of time horizon. It means that under the given constraints, it is better to keep the unirrigated land as fallow and divert the scarce resources to other crops in order to optimize income. Though the cultivation of traditional crops for sustainable landscape development in these mountains have been strongly recommended (Nautiyal \& Kaechele, 2007), but factors, such as profits, risk and input availability plays more significant role in determining the crop plan.

By relaxing the capital availability constraint by two percent in Scenario 3, the irrigated land is speedily occupied by carnation. Consequently, it reduces the land area under tomato in both seasons in direct proportions (Fig. 3). It helps in raising the TDGM to 1,091,551 thousand rupees, the highest level in any of the model scenario. This clearly depicts the importance of capital for such ventures, which helps in maximization of income of the farmers.

In the scenario 4, unirrigated land in rabi season is reduced annually by 3.11 percent followed by an increase in irrigation facilities by 2 percent. These rates have been taken so as to maintain the total land area at current level at the end of model horizon. With the increase in irrigation facilities on more land, it is only tomato which occupies the newly irrigated land (Fig. 4). Though the level of TDGM is slightly higher than in the scenario 2, but the risk level as reflected by VIT is also very high. It means that with the higher cultivation of tomato, farmers have to bear more risk. 
The scenario 5 is based on maximization of TDGM by fixing the VIT at the level as calculated in scenario 1 . This is done for knowing the optimum cropping pattern with the risk level of existing plan. The TDGM is maximized at 602,388 thousand rupees, which is near double than the existing plan. It means that this cropping plan has a potential to double the income with the current level of risk. Capsicum and beans, which were non existent in the earlier optimum plans, are now grown on more land than the tomato (Fig. 5). Similarly, in the rabi season, peas completely replaces tomato on irrigated land, whereas, wheat occupies all of the unirrigated land.

In this scenario, all crops with high risk in gross returns have been replaced by the crops with less risk level. By comparing it to the existing plan, it is observed that the farmers are more considerate to risk than the profits. Therefore, they diversify agriculture by cultivating several crops with low risk level than only a few crops that maximize the income. This is supported by many evidences which suggest that individuals have reasonably accurate perceptions of risks, which have a fundamental impact on their welfare (Amaresh \& Omar, 2008). However, crops such as, maize and barley, which are dominant crops in the watershed are missing in the optimum plans either due to less margins or due to the constraints of model.

As far as the labor requirements for agricultural activities are concerned, farmers in the watershed seem self sufficient except in two or three peak season months in optimizing plan 2, 3 and 4. Forest activities that are not included in this model will further strengthen the pressure on human labor in the peak season. The labor requirements are bound to increase manifold with the emerging cropping patterns, requiring higher human labor (Chand, 1997). During peak season, labor requirements grow continuously over model horizon in all the scenarios.

\section{Conclusions}

Growing cash requirements of the farmers have favorably affected the farm enterprise, resulting in rapid shift in traditional cropping patterns towards cash crops of vegetables and flowers. Though the farmers suitably diversify their cropping pattern due to risk considerations yet the knowledge of optimized cropping plans may further suggest some better options for raising income levels. The efforts at calculating costs, returns and risks for the new emerging profitable as well as riskier crops, can help farmers in selecting appropriate crop combinations. Such knowledge dissemination at micro level should be supplemented with the suitable policy interventions for timely supply of necessary farm inputs and credit facilities.

In addition to flowers, the production of continental vegetables in the controlled conditions can be equally profitable and also provide necessary crop rotations. Permanent irrigation facility is the main factor that facilitates the cultivation of cash crops. It not only helps in attaining higher income levels, but also saves scarce farm resources from traditional crops, which are mostly economically unviable in the hilly regions. Therefore, more irrigation facilities are needed for these profitable enterprises in the entire watershed. Water for irrigation in the region comes from the Chabri rivulet that drains from this cedar and oak forested watershed. Therefore, the tree species like oak should be properly conserved and propagated for better water conservation. Construction of check dams and water reservoirs, rain water harvesting and lift irrigation systems with equitable and judicious water distribution are also required for the growing agricultural intensification across the villages.

Policy interventions from government towards more irrigation facilities, better transportation network and development of new market yards can prove useful in achieving large scale production of vegetables and flowers. Such intensification of agriculture has the potential not only to increase the living standard of farmers but also provide self employment in the state.

\section{Acknowledgements}

Financial support by the Integrated Institute of Himalayan Studies (UGC Center of Excellence), Shimla, India (Project Number 9-3/2005) and Norwegian University of Life Sciences, Aas, Norway (Sub Project Number 1526010, Main Project No. 11526010) is gratefully acknowledged. Thanks are also due to International Association of Agricultural Economists (IAAE), for funding the 'Beijing-2009 Conference' visit to present this work.

\section{References}

Amaresh, D. \& Omar, A. (2008). Risk perception, behavior and optimizing models: comments. European Journal of Economics, Finance and Administrative Sciences, 11, 136-142.

Bhatti, J.P., Garg, S.K. \& Singh, R. (2002). Strategy for agricultural development in the western Himalayan region of India: Economic and environmental dimensions. In: Dajue, L. (ed.), Proceedings of Second International Conference on Sustainable Agriculture for Food, Energy and Industry. Beijing: Institute of Botany, Chinese Academy of Sciences.

Brooke, A., Kendrick, D., Meeraus, A. \& Raman, R. (1998). GAMS User's Guide, Washington DC, USA: GAMS Development Corporation.

Chand, R. (1997). Agricultural Diversification and Development of Mountain Regions - With Special Reference to Himachal Pradesh. New Delhi: M. D. Publications. 
Gohp. (2002). Himachal Pradesh Human Development Report 2002. Shimla: Government of Himachal Pradesh.

Gohp. (2005). Management Plan of Chail Wildlife Sanctuary, Plan Period 1999-00 to 2008-09. Shimla: H.P. Forest Department, Govt. of Himachal Pradesh.

Hazel, P.B.R. (1971). A linear alternative to quadratic and semi variance programming for farm planning under uncertainty. American Journal of Agricultural Economics, 53, 53-62.

Jodha, N.S. (2005). Adaptation strategies against growing environmental and social vulnerabilities in mountain areas. Himalayan Journal of Sciences, 3, 33-42.

Mysore, S. \& Uva, W.L. (2000). International Competition in the Greenhouse Production of Floriculture Products Lessons for New York and India. Ithaca, NY: Dept. of Agricultural, Resource, and Managerial Economics, Cornell University.

Nautiyal, S. \& Kaechele, H. (2007). Conservation of crop diversity for sustainable landscape development in the mountains of the Indian Himalayan region. Management of Environmental Quality: An International Journal, 18, 514-530.

Olarinde, L.O. Manyong, V.M. \& Okoruwa, V.O. (2008). Analyzing optimum and alternative farm plans for risk averse grain crop farmers in Kaduna state, northern, Nigeria. World Journal of Agricultural Sciences, 4, 28-35.

Pokhriyal, H.C. \& Bist, N.S. (1998). Planning for agricultural development in the Himalayan region: An environmental approach. The Environmentalist, 8, 47-55.

Powell, J.M., Pearson, R.A. \& Hiernaux, P.H. (2004). Crop-livestock interactions in the west African dry lands. Agronomy Journal, 96, 469-483.

Sankhayan, P.L., Gurung, N., Sitaula, B.K. \& Hofstada, O. (2003). Bio-economic modeling of land use and forest degradation at watershed level in Nepal. Agriculture, Ecosystems \& Environment, 94, 105-116.

Sankhayan, P.L. \& Hofstad, O. (2001). A village-level economic model of land clearing, grazing, and wood harvesting for sub-Saharan Africa: with a case study in southern Senegal. Ecological Economics, 38, 423-440.

Sharma, H.R. (2005). Agricultural development and crop diversification in Himachal Pradesh: understanding the patterns, processes, determinants and lessons. Indian Journal of Agricultural Economics, 60, 71-93.

Sharma, R.K., Sankhayan, P.L. \& Hofstad, O. (2008). Forest biomass density, utilization and production dynamics in a western Himalayan watershed. Journal of Forestry Research, 19, 171-180.

Sharma, R.K., Sankhayan, P.L., Hofstad, O. \& Singh, R. (2007). Land use changes in the western Himalayan region - a study at watershed level in the state of Himachal Pradesh, India. International Journal of Ecology and Environmental Sciences, 33, 197-206.

Singh, R., Rattan, R.S. \& Bhatti, J.P. (2000). Technological changes in marketing of hill farm products: A study of Himachal Pradesh. Indian Journal of agricultural Marketing, 14, 63-71.

Singh, R., Vaidya, C.S. \& Karol, A. (2006). Likely Demand of Vegetables of Himachal Pradesh in the Neighboring Consuming States during Next Ten Years. Shimla: Agro-Economic Research Centre.

Tulachan, P. M., \& Neupane, A. (1999). Livestock in Mixed Farming Systems of the Hindu Kush-Himalayas: Trends and Sustainability. Kathmandu: International Centre for Integrated Mountain Development. 
Table 1. Brief description of model scenarios

\begin{tabular}{|c|c|c|c|c|c|}
\hline S.N & $\begin{array}{l}\text { Abbreviation for } \\
\text { model scenario }\end{array}$ & Objective & $\begin{array}{c}\text { TDGM } \\
\text { (in rupees) }\end{array}$ & $\begin{array}{c}\text { VIT } \\
\text { (in rupees) }\end{array}$ & Brief explanation of model scenario \\
\hline 1 & $\mathrm{EP}$ & $\begin{array}{c}\text { Calculation of } \\
\text { TDGM and VIT }\end{array}$ & 321278 & 3327000 & $\begin{array}{l}\text { Area under crops as exists in year } 2006 \\
\text { is fixed for the model horizon }\end{array}$ \\
\hline 2 & MTDGM & $\begin{array}{l}\text { Maximization of } \\
\text { TDGM }\end{array}$ & 785837 & 243237200 & $\begin{array}{l}\text { Neither the activity nor the VIT is } \\
\text { fixed. }\end{array}$ \\
\hline 3 & MTDGM-HRI & $\begin{array}{l}\text { Maximization of } \\
\text { TDGM }\end{array}$ & 1091551 & 152722600 & $\begin{array}{l}\text { Capital constraint is relaxed by two } \\
\text { percent }\end{array}$ \\
\hline 4 & MTDGM-HI & $\begin{array}{l}\text { Maximization of } \\
\text { TDGM }\end{array}$ & 814264 & 275470300 & $\begin{array}{l}\text { Irrigated area in rabi season is } \\
\text { increased by } 2 \% \text { p.a. and the } \\
\text { unirrigated area is reduced by } 3.11 \%\end{array}$ \\
\hline 5 & MTDGM-FV & $\begin{array}{l}\text { Maximization of } \\
\text { TDGM }\end{array}$ & 602388 & 3327000 & VIT found in scenario 1 is fixed \\
\hline
\end{tabular}

Table 2. Existing cropping pattern in the watershed (Area in hectares)

\begin{tabular}{|c|c|c|c|c|c|c|c|}
\hline & Crop & $\begin{array}{l}\text { Crop growing } \\
\text { months }\end{array}$ & $\begin{array}{l}\text { Total } \\
\text { Area }\end{array}$ & Irrigated & Unirrigated & Fertilized & $\begin{array}{c}\text { Non } \\
\text { Fertilized }\end{array}$ \\
\hline \multicolumn{8}{|l|}{ Kharif crops (Rainy) } \\
\hline \multirow{5}{*}{ Vegetables: } & Capsicum & July-October & 6.48 & 6.48 & 0 & 6.48 & 0 \\
\hline & Tomato & July-October & 6.02 & 6.02 & 0 & 6.02 & 0 \\
\hline & Beans & July-October & 5.48 & 3.4 & 2.08 & 3.9 & 1.58 \\
\hline & Potato & July-October & 1.64 & 1.64 & 0 & 1.64 & 0 \\
\hline & Cabbage & July-October & 0.16 & 0.16 & 0 & 0.16 & 0 \\
\hline \multirow{5}{*}{ Other crops: } & Maize & July-October & 28.18 & 13.2 & 14.98 & 13.76 & 14.42 \\
\hline & Pulses & July-October & 2.44 & 1.8 & 0.64 & 1.9 & 0.54 \\
\hline & Ginger & July-October & 0.28 & 0.28 & 0 & 0 & 0.28 \\
\hline & $\begin{array}{l}\text { Miscl./Kharif } \\
\text { Fallow }\end{array}$ & July-October & 9.27 & 3 & 6.27 & 2.5 & 6.77 \\
\hline & Total Kharif & & 59.95 & 35.98 & 23.97 & 36.36 & 23.59 \\
\hline \multicolumn{8}{|l|}{ Rabi Crops (Winter) } \\
\hline \multirow{5}{*}{ Vegetables: } & Tomato & March-June & 5.22 & 5.22 & 0 & 5.22 & 0 \\
\hline & Capsicum & March-June & 5.20 & 5.20 & 0 & 5.20 & 0 \\
\hline & Peas & Nov-June & 2.36 & 2.36 & 0 & 2.36 & 0 \\
\hline & Potato & March-June & 0.68 & 0.68 & 0 & 0.68 & 0 \\
\hline & Cabbage & March-June & 0.04 & 0.04 & 0 & 0.04 & 0 \\
\hline \multirow[t]{7}{*}{ Other crops: } & Barley & Nov-June & 10.76 & 4.24 & 6.52 & 0 & 10.76 \\
\hline & Wheat & Nov-June & 9.85 & 3.56 & 6.29 & 0 & 9.85 \\
\hline & Garlic & Nov-June & 0.92 & 0.92 & 0 & 0.92 & 0 \\
\hline & Ginger & March-June & 0.37 & 0.37 & 0 & 0 & 0.37 \\
\hline & Mustard & Nov-June & 0.16 & 0.04 & 0.12 & 0 & 0.16 \\
\hline & $\begin{array}{l}\text { Miscl. / Rabi } \\
\text { fallow }\end{array}$ & Nov-June & 24.39 & 0.62 & 23.77 & 6 & 18.39 \\
\hline & Total Rabi & & 59.95 & 23.25 & 36.7 & 20.42 & 39.53 \\
\hline \multicolumn{8}{|l|}{ Annual Crops } \\
\hline \multirow[t]{5}{*}{ Flowers: } & Gladiolus & July-June & 3.04 & 3.04 & 0 & 3.04 & 0 \\
\hline & Carnation & July-June & 3.08 & 3.08 & 0 & 3.08 & 0 \\
\hline & Chrysanthemum & July-June & 1.72 & 1.72 & 0 & 1.72 & 0 \\
\hline & Lily & July-June & 0.35 & 0.35 & 0 & 0.35 & 0 \\
\hline & Total Flowers & & 8.19 & 8.19 & 0 & 8.19 & 0 \\
\hline Fruit Crops & Fruit crops & July-June & 7.08 & 0 & 7.08 & 0 & 7.08 \\
\hline
\end{tabular}

Note- Crops grown on less than .5 ha are not considered in the model 
Table 3. Paid-out cost and gross margins from crops in the watershed (rupees $\mathrm{ha}^{-1}$ )

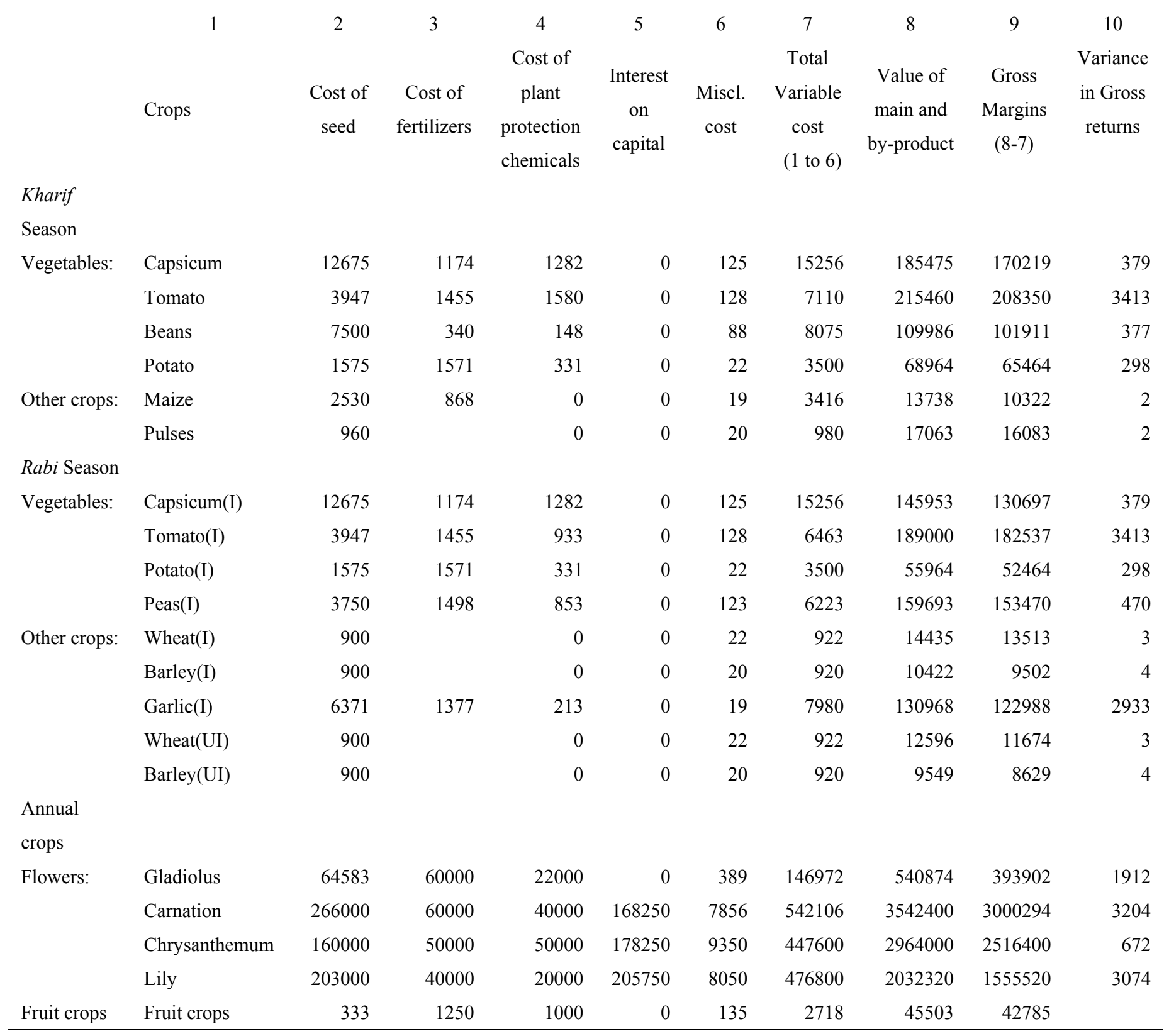


Table 4. Annual paid-out cost and gross margins per livestock head in the watershed (Rupees)

\begin{tabular}{|c|c|c|c|c|c|c|}
\hline Livestock & $\begin{array}{c}2 \\
\text { Number }\end{array}$ & $\begin{array}{c}3 \\
\text { Value of } \\
\text { inputs } \\
\text { bought }\end{array}$ & $\begin{array}{c}4 \\
\text { Value of } \\
\text { Main } \\
\text { Product }\end{array}$ & $\begin{array}{c}5 \\
\text { Value of } \\
\text { By-Product }\end{array}$ & $\begin{array}{c}6 \\
\text { Total } \\
\text { Value } \\
(4+5) \\
\end{array}$ & $\begin{array}{c}7 \\
\text { Gross } \\
\text { Margins } \\
(6-3) \\
\end{array}$ \\
\hline Cross bred cow (in milk) & 77 & 2000 & 20748 & 274 & 21022 & 19022 \\
\hline Cross bred cow (dry) & 8 & 1000 & 0 & 228 & 228 & -772 \\
\hline Cross bred Heifer & 7 & 100 & 0 & 91 & 91 & -9 \\
\hline Cross bred young stock male & 31 & 100 & 0 & 46 & 46 & -54 \\
\hline Cross bred young stock female & 39 & 100 & 0 & 46 & 46 & -54 \\
\hline Cross bred bullock & 12 & 800 & 0 & 183 & 183 & -618 \\
\hline Local cow (in milk) & 69 & 900 & 8148 & 160 & 8308 & 7408 \\
\hline Local cow (dry) & 30 & 300 & 0 & 137 & 137 & -163 \\
\hline Local heifer & 5 & 120 & 0 & 68 & 68 & -52 \\
\hline Local young stock male & 29 & 100 & 0 & 37 & 37 & -64 \\
\hline Local young stock female & 31 & 100 & 0 & 37 & 37 & -64 \\
\hline Local bullock & 102 & 800 & 0 & 137 & 137 & -663 \\
\hline Buffalo (in milk) & 19 & 1400 & 16488 & 274 & 16762 & 15362 \\
\hline Buffalo (dry) & 10 & 750 & 0 & 228 & 228 & -522 \\
\hline Buffalo young stock male & 1 & 100 & 0 & 137 & 137 & 37 \\
\hline Buffalo young stock female & 1 & 100 & 0 & 137 & 137 & 37 \\
\hline
\end{tabular}

Table 5. Variance-covariance matrix of per hectare gross returns from crops over the last five years (in million rupees)

\begin{tabular}{lrrrrrrrrrr}
\hline & Maize & Capsicum & Tomato & \multicolumn{1}{c}{ Beans } & Pulses & Potato & Wheat(I) & Barley(I) & Peas(I) & Garlic(I) \\
\hline Maize & 2 & 3 & -26 & 7 & -1 & 10 & 0 & -1 & -17 & 68 \\
Capsicum & 3 & 379 & -518 & -70 & -11 & -280 & 4 & 20 & 115 & 1866 \\
Tomato & -26 & -518 & 1209 & -265 & 41 & 227 & 31 & 2 & 276 & -2891 \\
Beans & 7 & -70 & -265 & 377 & -23 & 98 & -46 & -33 & -370 & -519 \\
Pulses & -1 & -11 & 41 & -23 & 2 & 3 & 3 & 2 & 25 & -51 \\
Potato & 10 & -280 & 227 & 98 & 3 & 298 & -2 & -19 & -195 & -1013 \\
Wheat(I) & 0 & 4 & 31 & -46 & 3 & -2 & 8 & 5 & 48 & 59 \\
Barley(I) & -1 & 20 & 2 & -33 & 2 & -19 & 5 & 4 & 41 & 100 \\
Peas(I) & -17 & 115 & 276 & -370 & 25 & -195 & 48 & 41 & 470 & 351 \\
Garlic(I) & 68 & 1866 & -2891 & -519 & -51 & -1013 & 59 & 100 & 351 & 11210 \\
Wheat(UI) & 0 & 4 & 31 & -46 & 3 & -2 & 8 & 5 & 48 & 59 \\
Barley(UI) & -1 & 20 & 2 & -33 & 2 & -19 & 5 & 4 & 41 & 100 \\
Capsicum(I) & 3 & 379 & -518 & -70 & -11 & -280 & 4 & 20 & 115 & 1866 \\
Tomato(I) & -26 & -518 & 1209 & -265 & 41 & 227 & 31 & 2 & 276 & -2891 \\
Potato(I) & 10 & -280 & 227 & 98 & 3 & 298 & -2 & -19 & -195 & -1013 \\
Gladiolus & 162 & 954 & 146 & -3618 & 149 & 336 & 449 & 234 & 1811 & 14229 \\
Carnation & 539 & -3857 & 9992 & -11169 & 687 & 6657 & 1426 & 377 & 3535 & 15475 \\
Chrysanthemum & -76 & -686 & 1112 & 426 & 56 & 228 & 75 & 56 & 631 & -6473 \\
Lily & 146 & 584 & -2889 & 994 & -134 & 450 & -158 & -128 & -1970 & 6631 \\
\hline & & & & & & & & &
\end{tabular}


Table 5 (Continued)

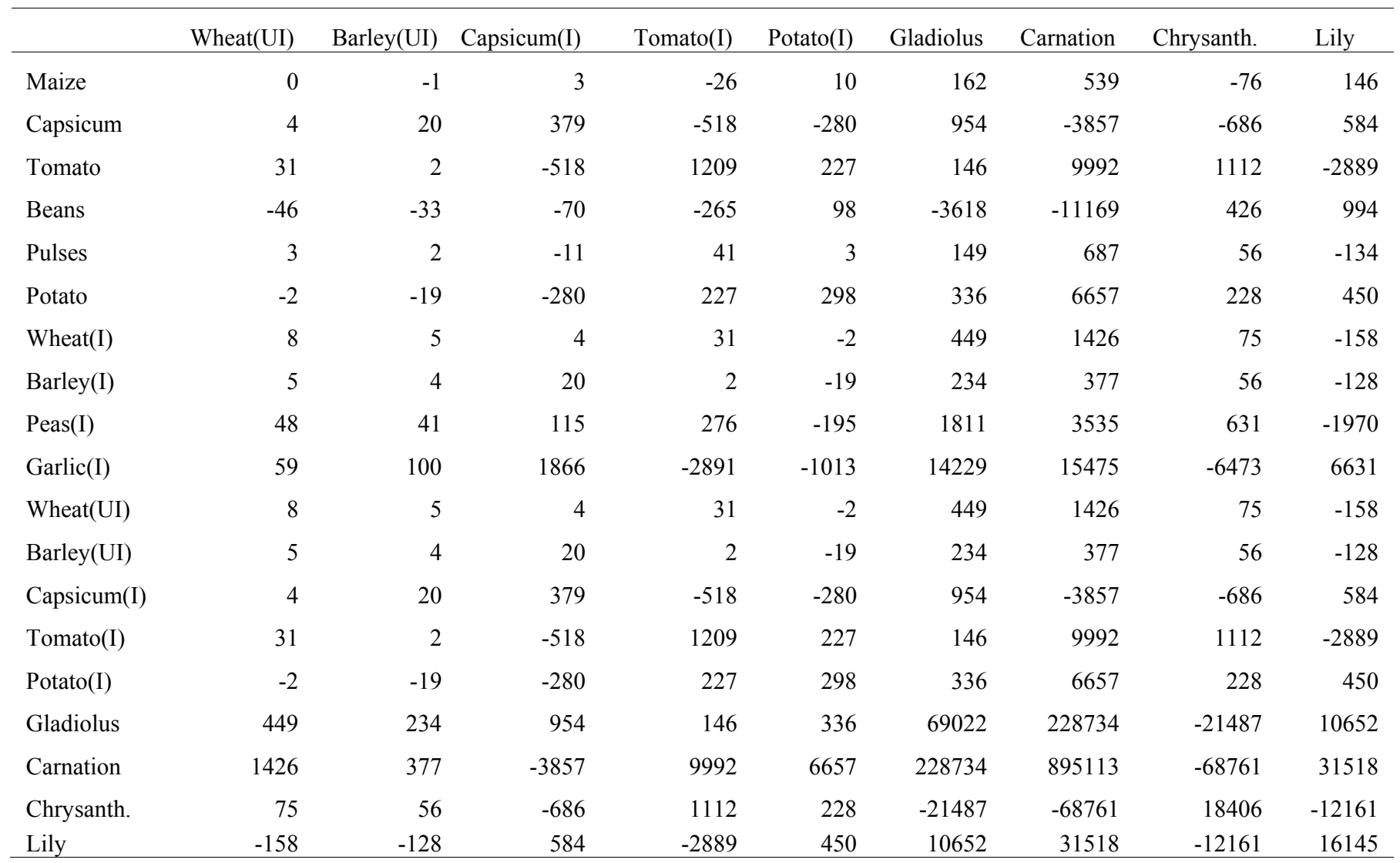

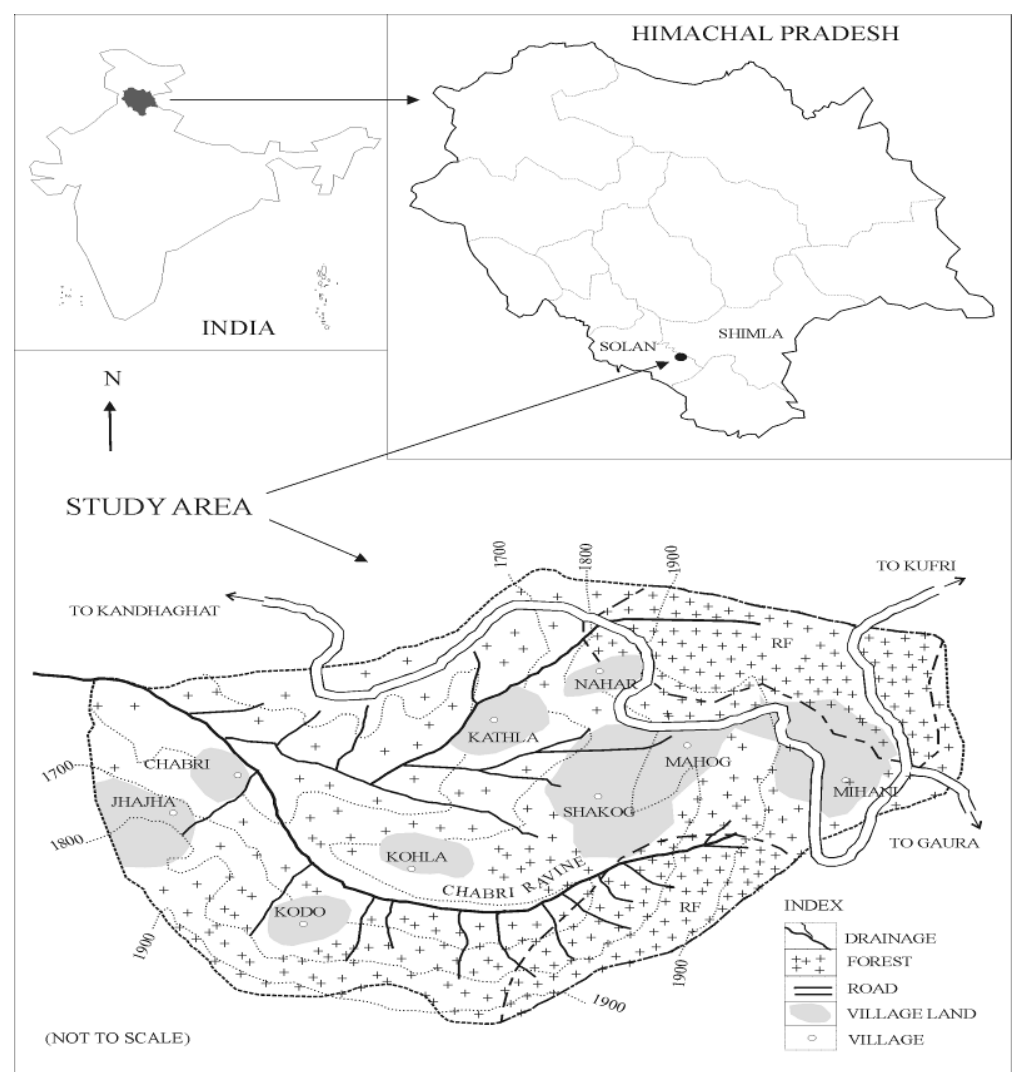

Figure 1. Map of the study area 


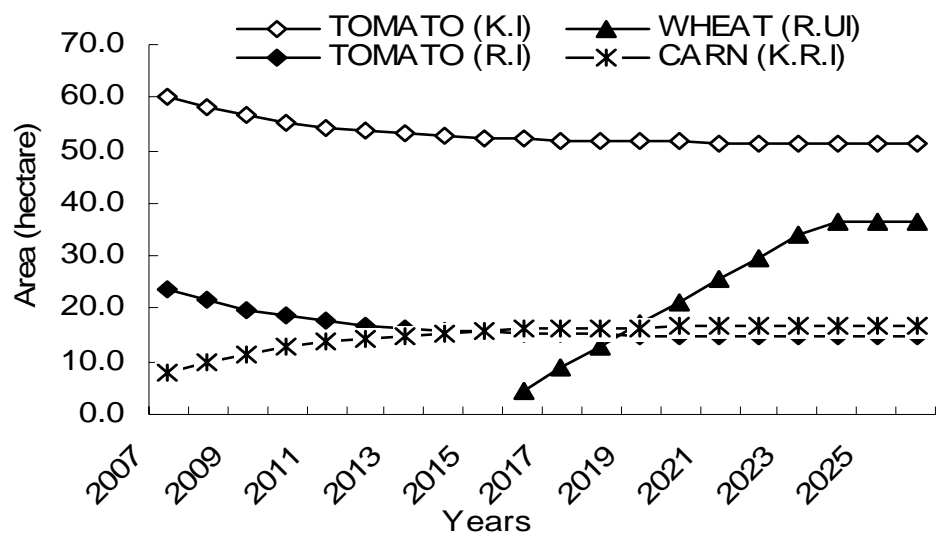

Figure 2. Cropping pattern in scenario 2 over model horizon

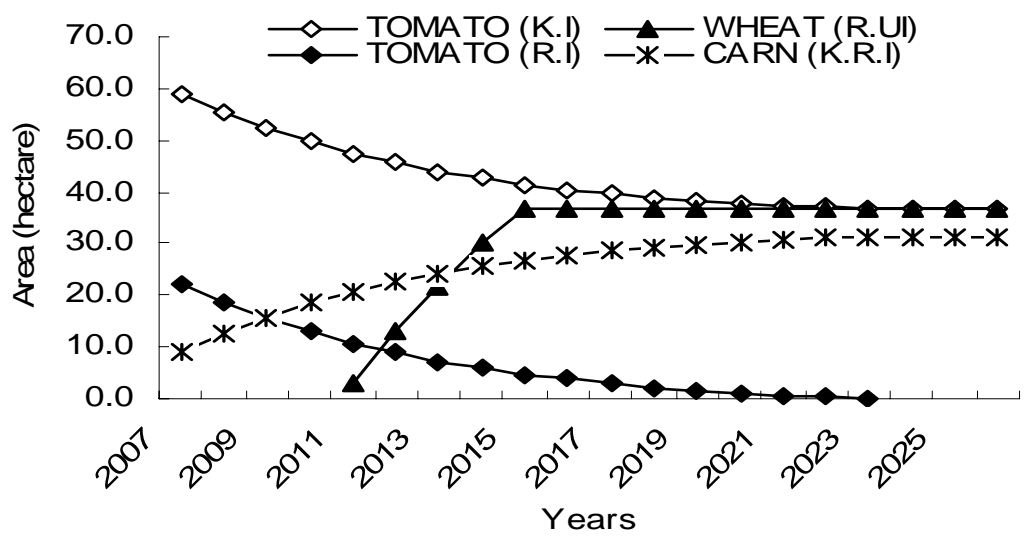

Figure 3. Cropping pattern in scenario 3 over model horizon

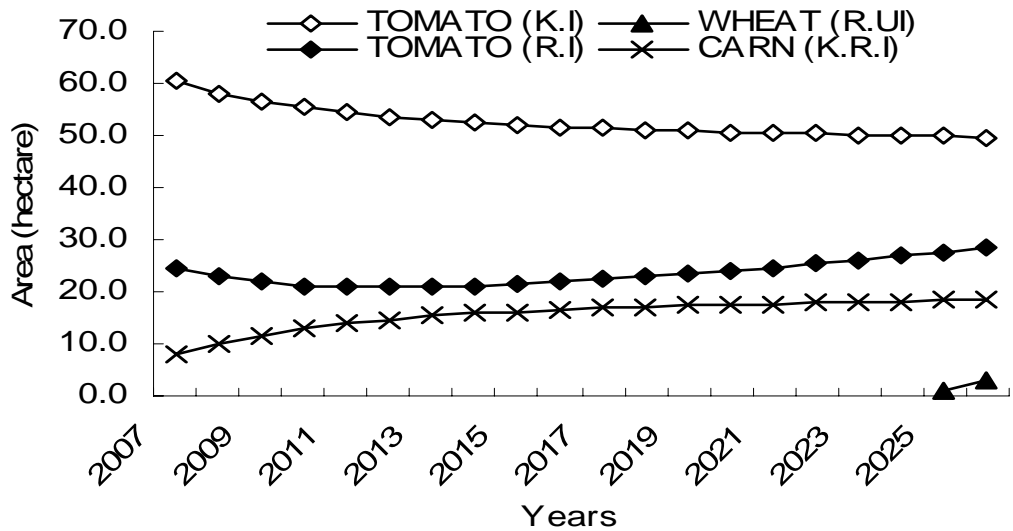

Figure 4. Cropping pattern in scenario 4 over model horizon 


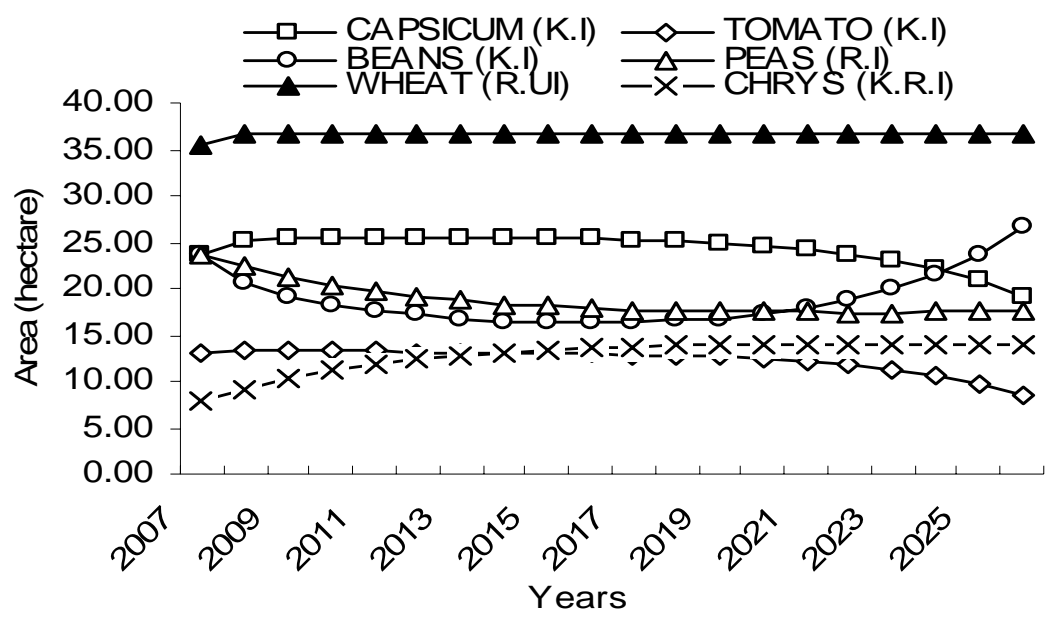

Figure 5. Cropping pattern in scenario 5 over model horizon 